\title{
COVID 19 Pandemic: A Real-time Forecasts \& Prediction of Confirmed Cases, Active Cases using the ARIMA model \& Public Health in West Bengal, India.
}

\author{
Dibash Sarkar *,a,b, Moinak Biswas ${ }^{a, b}$. \\ a. Department of Biotechnology, \\ b. Adamas University, Kolkata, India \\ * First Author \& Corresponding Author
}

\begin{abstract}
Background: COVID-19 is an emerging infectious disease which has been declared a Pandemic by the World Health Organization (WHO) on March 11 2020. This pandemic has spread over the world in more than 200 countries. India is also adversely affected by this pandemic, and there are no signs of slowing down of the virus in coming time. The absence of a vaccine for COVID-19 is making the situation worse for the already overstretched Indian public health care system. As economic burden makes it increasingly difficult for our country to continue imposing control measures, it is vital for states like West Bengal to make predictions using time series forecasting for the upcoming cases, test kits, health care and estimated the requirement of Quarantine centers, isolation beds, ICU beds and ventilators for COVID-19 patients .
\end{abstract}

Objective: This study is forecasting the confirmed and active cases for COVID-19 until August, using time series ARIMA model \& Public Health in West Bengal, India.

Methods: We used ARIMA model, and Auto ARIMA model for forecasting confirmed and active cases till the end of August month using time series data of COVID-19 cases in West Bengal, India from March 1, 2020, to June 4, 2020.

Results: We are expecting that West Bengal will have around $\mathbf{6 2 2 7 9} \pm \mathbf{5 0 0 0}$ Cases by the end of August based on our forecasts. Meanwhile Maharashtra, Punjab, Gujarat and Delhi (UT) will be the most affected states, having the highest number of active and confirmed cases at the end of August.

Discussion and Conclusion: This forecasts show a very crucial situation for West Bengal in coming days and, the actual numbers can go higher than our estimates of confirmed case as Lockdown 5.0 \& Unlock 1.0 will be implemented from $1^{\text {st }}$ June 2020 in India, West Bengal will be observing a partial lift of the lockdown and in that case, there will be a surge in the number of daily confirmed and active cases. The requirement of Health care sector needs to be further improved isolation beds, ICUs and ventilators will also be needed to increase in that scenario. Inter State \& Intra State Movement restrictions are lifted. Hence, Migrants returning to their homes due to loss of livelihood and income in the lockdown period may lead to a rise in the number of cases, which could not be accounted for in our projections. We suggest more of Public-Private Partnership (PPP) model in the health sector to accommodate COVID-19 patients adequately and reduce the burden of the already overstretched Indian public health care system, which will directly or indirectly affect the States in the time of crisis.

Keywords: COVID 19, India, Forecast, ARIMA, Health Infrastructure, State-level analysis. 
medRxiv preprint doi: https://doi.org/10.1101/2020.06.06.20124180; this version posted June 8, 2020. The copyright holder for this preprint (which was not certified by peer review) is the author/funder, who has granted medRxiv a license to display the preprint in perpetuity. It is made available under a CC-BY-NC-ND 4.0 International license .

\section{Introduction}

Coronavirus disease (COVID-19) is one of the greatest challenges the world has encountered in recent times. Since the initial reports of outbreak in late December, 2019, It is caused by severe acute respiratory syndrome Corona Virus 2 (SARS-CoV-2). The origin of the virus is yet to be confirmed, but the first person tested positive is from Wuhan, China. It is spreading very quickly throughout the world \& the numbers have been consistently rising with the disease affecting 6.54 million people in 181 countries worldwide as of $6^{\text {th }}$ June, 2020. In India, the first positive case of COVID-19 was detected on January $30^{\text {th }} 2020$, in Kerala. The frailty of a multitude of health care systems across the globe has been exposed by COVID-19. With the surfacing negative socioeconomic consequences of community mitigation strategies like lockdown affecting the vulnerable, especially in developing countries like India, Governments are eyeing at easing the restrictions that have long been in place by recent Lockdown 5.0. It is imperative to understand that lifting the control measures for economic salvage, without thoroughly preparing for the possible consequences, may only result in further economic decline and health crisis.

WHO in its strategic advice for countries looking to life the control measures illustrated six criteria in a sequential manner to be considered: control of transmission; preparation of health systems for active contact tracing and optimum care provision; careful management of health facilities to prevent outbreaks; adherence to preventive measures as the essential services resume; management of importation risks; indoctrination of the 'new norm' among communities by active engagement. According to the report of World Population prospects (2019), India has a population of more than 1.36 billion and most of the population of urban areas and cities are under the risk of contracting the virus. So, it is important to forecast numbers of confirmed and active cases. In this scenario, it is vital for every state to make predictions using time series forecasting, the study aims to draw comparative account of the progression of COVID-19 in near future in the state of West Bengal.

\section{Data \& Methodology}

\section{Data:}

For our study, the required data of daily total confirmed cases and total active cases of COVID-19 infection collected for India as well as its state West Bengal from the (https://www.covid19india.org/), and excel of the patient database is used to build a time-series database for confirmed and active cases Using the Data Science Software called R . In this study, forecasting is done based on the data from March 1, 2020, to June 4 2020. This data is being used to build Forecast which includes all the Statistics and Graphs for mentioned model.

\section{Methodology:}

In the past few months, an increasing number of research related to forecasting the trend of pandemic COVID-19 cases are being published using different approaches in various part of the world. (Gupta and Pal 2020; Fanelli and Piazza 2020; Giordano et al. 2020; Tandon et al., 2020; Kumar et al. 2020; Benvenuto et al. 2020; Batista, 2020). The ARIMA model is one of them and nowadays used for forecasting case count for the prediction of epidemic diseases based on the time series modeling (Rios et al. 2000; Li et al. 2012; Zhang et al. 2014; Benvenuto et al., 2020).

In this study, the well-known Autoregressive Integrated Moving Average (ARIMA) time-series model used for the further forecasting purpose. ARIMA model is one of the generalized forms of an autoregressive moving average (ARMA) model among the time series forecasting. We fit both models to understand the data better or to predict future points in the series (Forecasting). ARIMA model depends or always represented with the help of some parameters, and the model has expressed as ARIMA (p, d, $\mathrm{q})$ : $\mathrm{p}, \mathrm{d}$ and $\mathrm{q}$ are non-negative integers. 
medRxiv preprint doi: https://doi.org/10.1101/2020.06.06.20124180; this version posted June 8, 2020. The copyright holder for this preprint (which was not certified by peer review) is the author/funder, who has granted medRxiv a license to display the preprint in perpetuity. It is made available under a CC-BY-NC-ND 4.0 International license .

The parameters have their usual meaning, here, $p$ stands for the order of auto-regression, $d$ represents the degree of trend difference (the number of times the data have had past values subtracted) for the stationary of the trend and $q$ signifies the order of moving average. This model combines auto regression lags under the stationary trend and moving average and predict better future values based on past and recent data. For this model, the degree of parameters $p, \mathrm{~d}$ and $\mathrm{q}$ determine based on the partial Autocorrelation function (PACF) graph, The Augmented Dickey-Fuller Test to test the stationary of the time series observations and Complete Auto-Correlation Function (ACF) graph respectively (Forecasting COVID-19 cases in India)

We have applied the ARIMA model and Auto ARIMA model using R, to our considered time series data of COVID-19 cases in West Bengal for the forecasting the total confirmed and active cases for West Bengal and its majorly affected Districts. We selected Districts based on the criterion that chosen Districts should have at least 2 confirmed cases till June $2^{\text {nd }} 2020$. By using this selection criterion, West Bengal and its 24 Districts Alipurduar, Bankura, Birbhum, Cooch Behar,

Dakshin Dinajpur (South Dinajpur), Darjeeling, Hooghly, Howrah, Jalpaiguri, Jhargram, Kalimpong, Kolkata ,Malda, Murshidabad, Nadia, North 24 Parganas, Paschim Medinipur (West Medinipur), Paschim (West) Burdwan (Bardhaman), Purba Burdwan (Bardhaman),

Purba Medinipur (East Medinipur), Purulia, South 24 Parganas, Uttar Dinajpur (North Dinajpur), The cases are forecasted under the assumption that people will be maintaining condition similar to the partial lockdown situation and maintain physical distancing with self quarantine. After fitting the model, the built model is used to forecast confirmed and active cases COVID-19 cases for the next 80 days, i.e. from June $6^{\text {rd }}, 2020$, to August $3^{\text {rd }} 2020$.

The model for forecasting future confirmed and active cases of COVID-19 cases is represented as,

$\operatorname{ARIMA}(p, \mathrm{~d}, \mathrm{q}): X t=\alpha 1 X t-1+\alpha 2 X t-2+\beta 1 Z t-1+\beta 2 Z t-2+Z \mathrm{t}$

Where, $Z t=X t-X t-1$

Here, $X t$ is the predicted number of confirmed and active COVID-19 cases at $t^{\text {th }}$ day; $\alpha 1, \alpha 2, \beta 1$ and $\beta 2$ are parameters whereas $Z t$ is the residual term for $t^{\text {th }}$ day.

The trend of forthcoming incidences can be estimated from the previous cases, and a time series analysis is performed for this purpose

(Tandon et. al., 2020).

In our study, the forecasted cases are mainly used for preparing the government of West Bengal for the health infrastructure such as the number of isolation beds, ICU beds and ventilators, Quarantine centers etc. across the State. In further analysis, based on predicted active cases, we estimated the hike in number of cases by COVID-19 patients in the coming days. Based on this theory we can maximize the requirement of Quarantine centers, Alcohol based Sanitizers, Public sanitizing materials, ICUs and ventilators as the infection hit its peak, which the state may get in the month of July-August according to the forecast.

Our health infrastructure requirement is estimated based on the active cases as our projections are made on the basis on data till June $2^{\text {nd }}$ when our country was observing the complete lockdown and starting of Lookdown 5.0. However, India is observing partial lockdown in Containment Zones currently and has removed lockdown in the Red, Yellow \& Green Zones, so for being prudent, we will estimate the amount of active cases which are to be increased and also look into the Public Health Infrastructure of West Bengal. 
medRxiv preprint doi: https://doi.org/10.1101/2020.06.06.20124180; this version posted June 8, 2020. The copyright holder for this preprint (which was not certified by peer review) is the author/funder, who has granted medRxiv a license to display the preprint in perpetuity.

It is made available under a CC-BY-NC-ND 4.0 International license .

\section{Results:}

Forecast of confirmed and active cases by the ARIMA model for West Bengal:

\section{Correlogram and ARIMA forecast graph for the Confirmed COVID-19 Cases in}

\section{West Bengal}

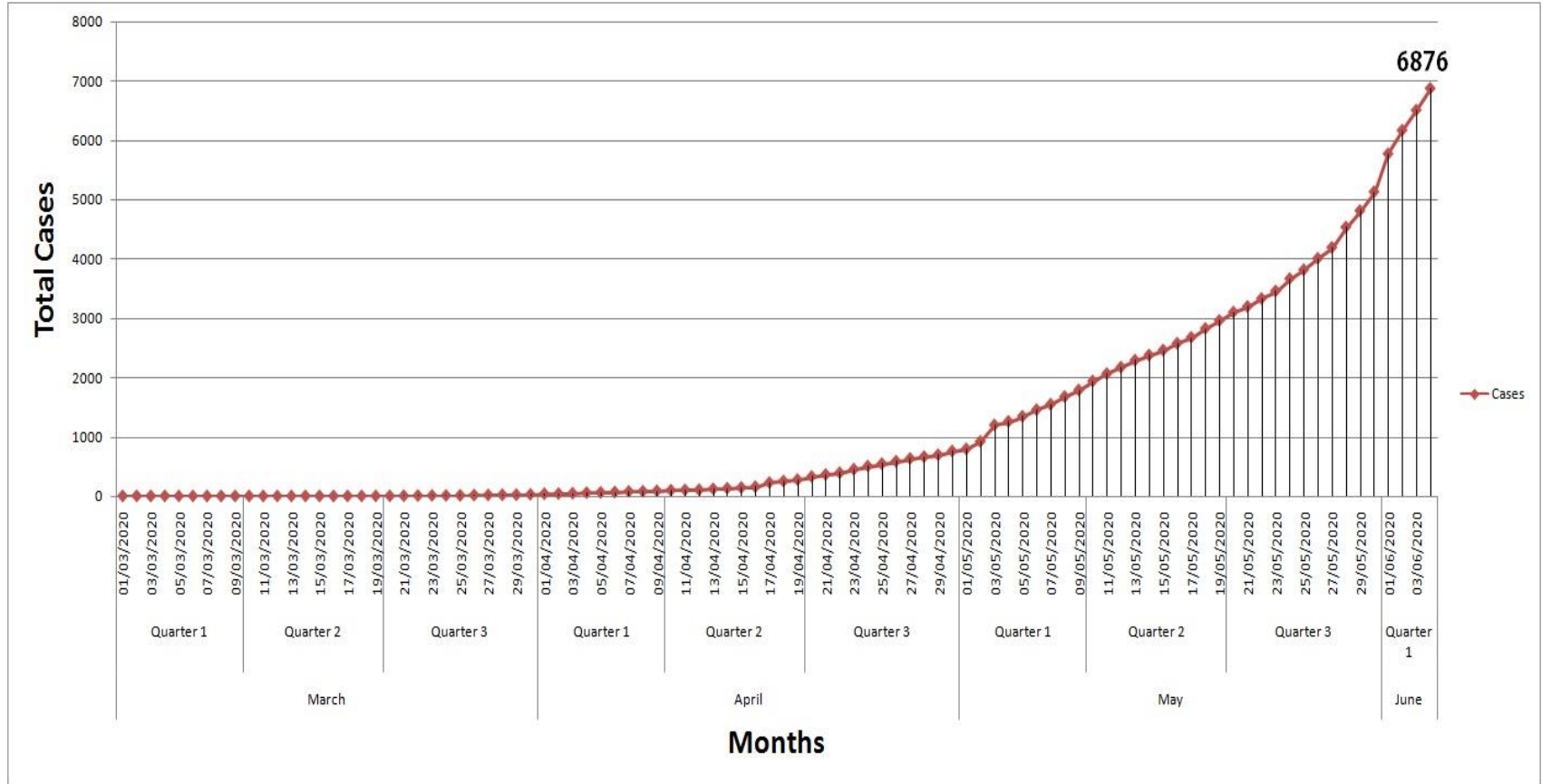

Fig. - Correlogram of Total COVID -19 Cases.

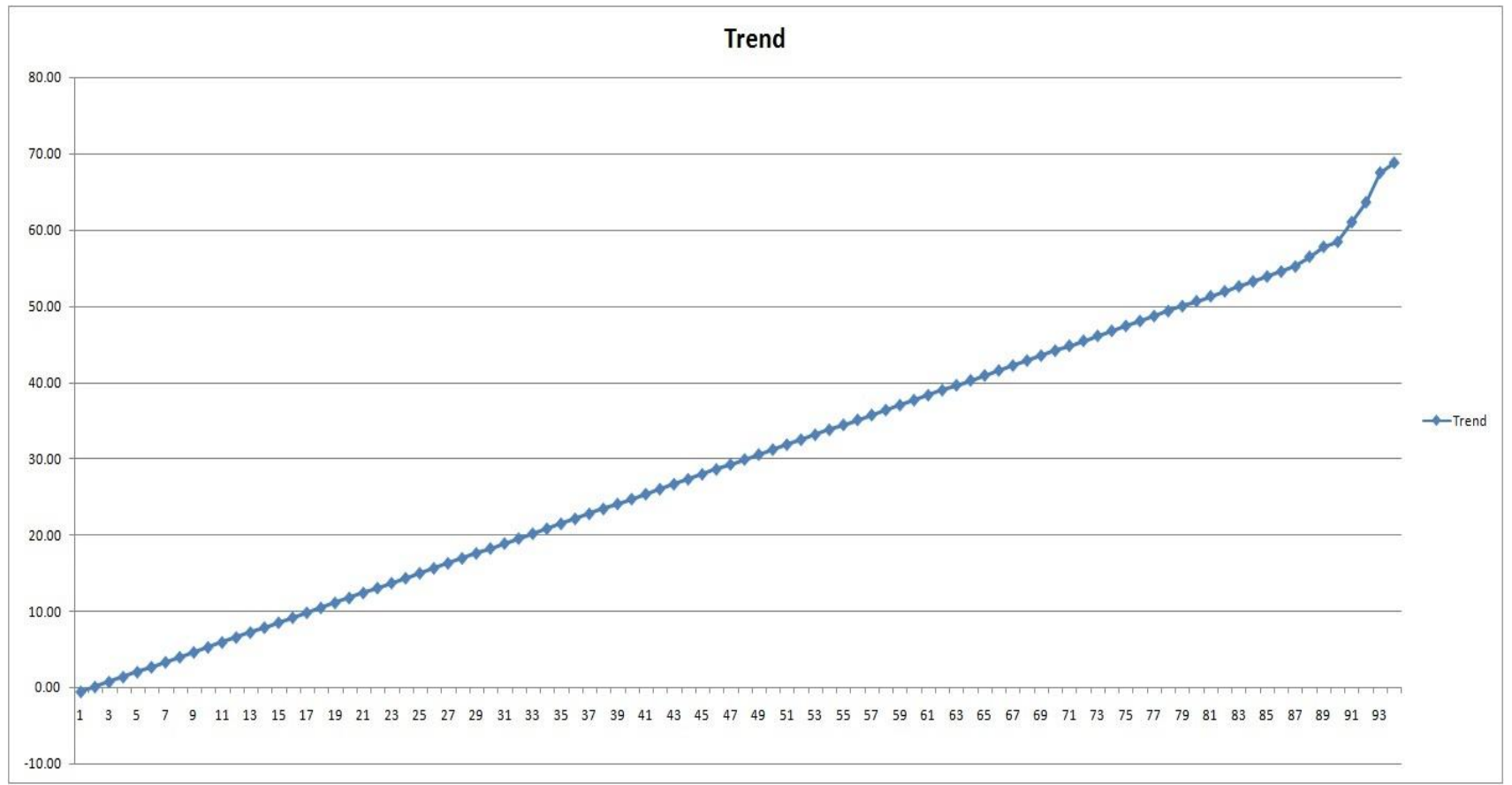

Fig. - Trend of COVID - 19 Cases in West Bengal. 
medRxiv preprint doi: https://doi.org/10.1101/2020.06.06.20124180; this version posted June 8, 2020. The copyright holder for this preprint (which was not certified by peer review) is the author/funder, who has granted medRxiv a license to display the preprint in perpetuity.

It is made available under a CC-BY-NC-ND 4.0 International license.

SUMMARY OUTPUT

\begin{tabular}{lr}
\hline \multicolumn{2}{c}{ Regression Statistics } \\
\hline Multiple R & 0.99997256 \\
R Square & 0.999945122 \\
Adjusted R Square & 0.999944525 \\
Standard Error & 8.377135212 \\
Observations & 94 \\
\hline
\end{tabular}

ANOVA

\begin{tabular}{|c|c|c|c|c|c|}
\hline & $d f$ & SS & MS & $F$ & Significance F \\
\hline Regression & 1 & 117639803.5 & 117639803.5 & 1676344.368 & $8.5371 E-198$ \\
\hline Residual & 92 & 6456.228281 & 70.17639436 & & \\
\hline Total & 93 & 117646259.7 & & & \\
\hline
\end{tabular}

\begin{tabular}{llcccrrrr}
\hline & Coefficients & \multicolumn{1}{l}{ Standard Error } & tStat & P-value & Lower 95\% & Upper 95\% & ower 95.0\% Upper 95.0\% \\
\hline Intercept & -1.237868533 & 1.05322687 & -1.175310437 & 0.242903314 & -3.329667961 & 0.853930895 & -3.32967 & 0.8539309 \\
X Variable 1 & 0.647888191 & 0.000500401 & 1294.737181 & $8.5371 E-198$ & 0.646894351 & 0.648882032 & 0.646894 & 0.64888203 \\
\hline
\end{tabular}

Fig. - Regression Table for the Total Data
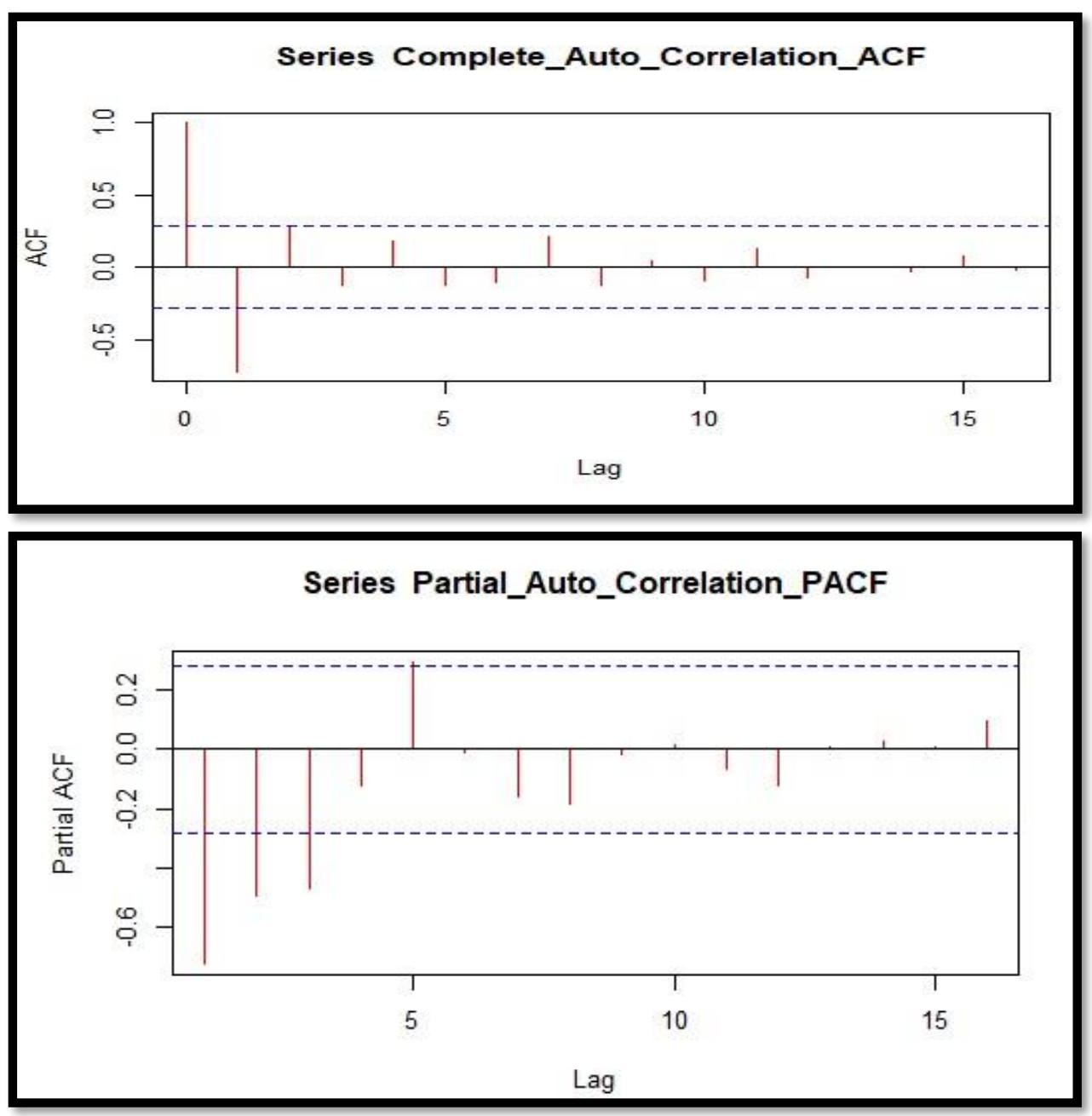

Fig. - The ACF and PACF plot for the determine the value of $q$ and $p$ for the model. 
medRxiv preprint doi: https://doi.org/10.1101/2020.06.06.20124180; this version posted June 8, 2020. The copyright holder for this preprint (which was not certified by peer review) is the author/funder, who has granted medRxiv a license to display the preprint in perpetuity.

\section{Forecasted Confired Cases in West Bengal By Arima $(1,3,1)$} For the month of June, July, August

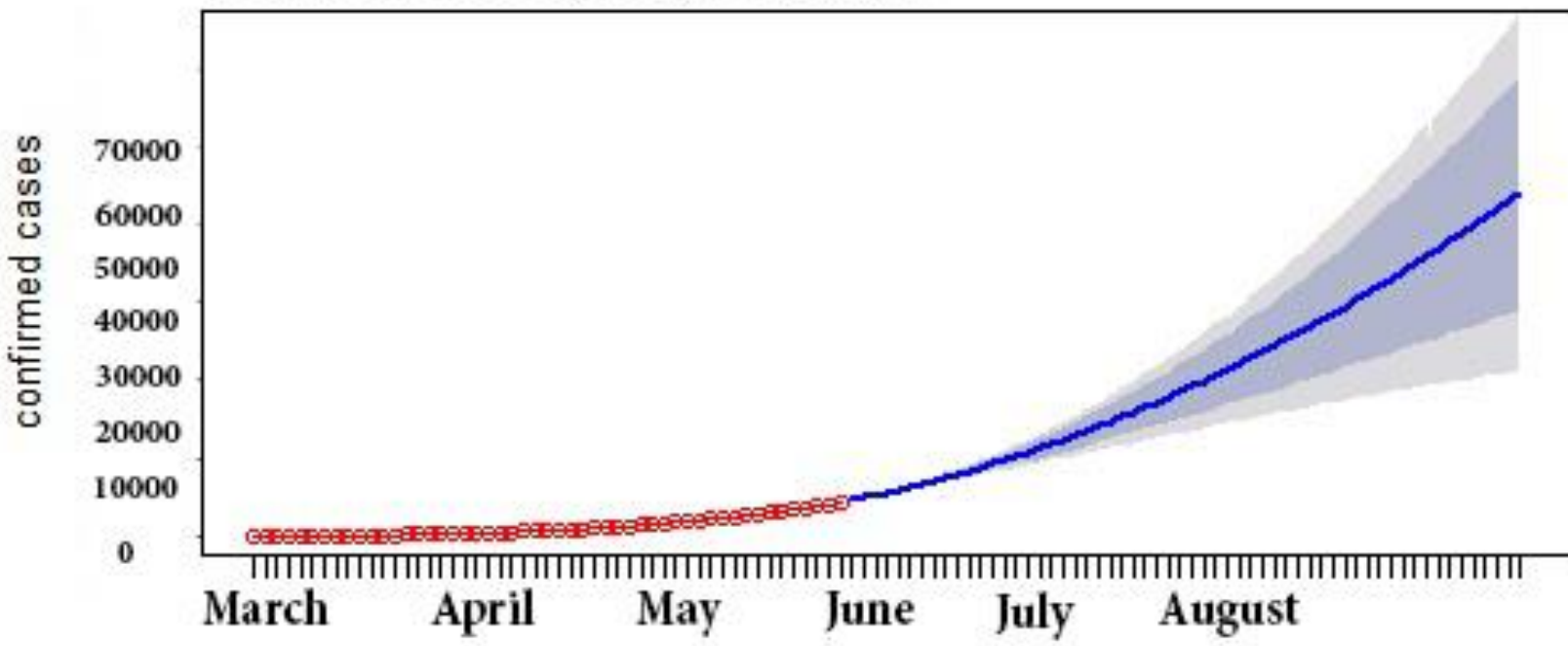

Date

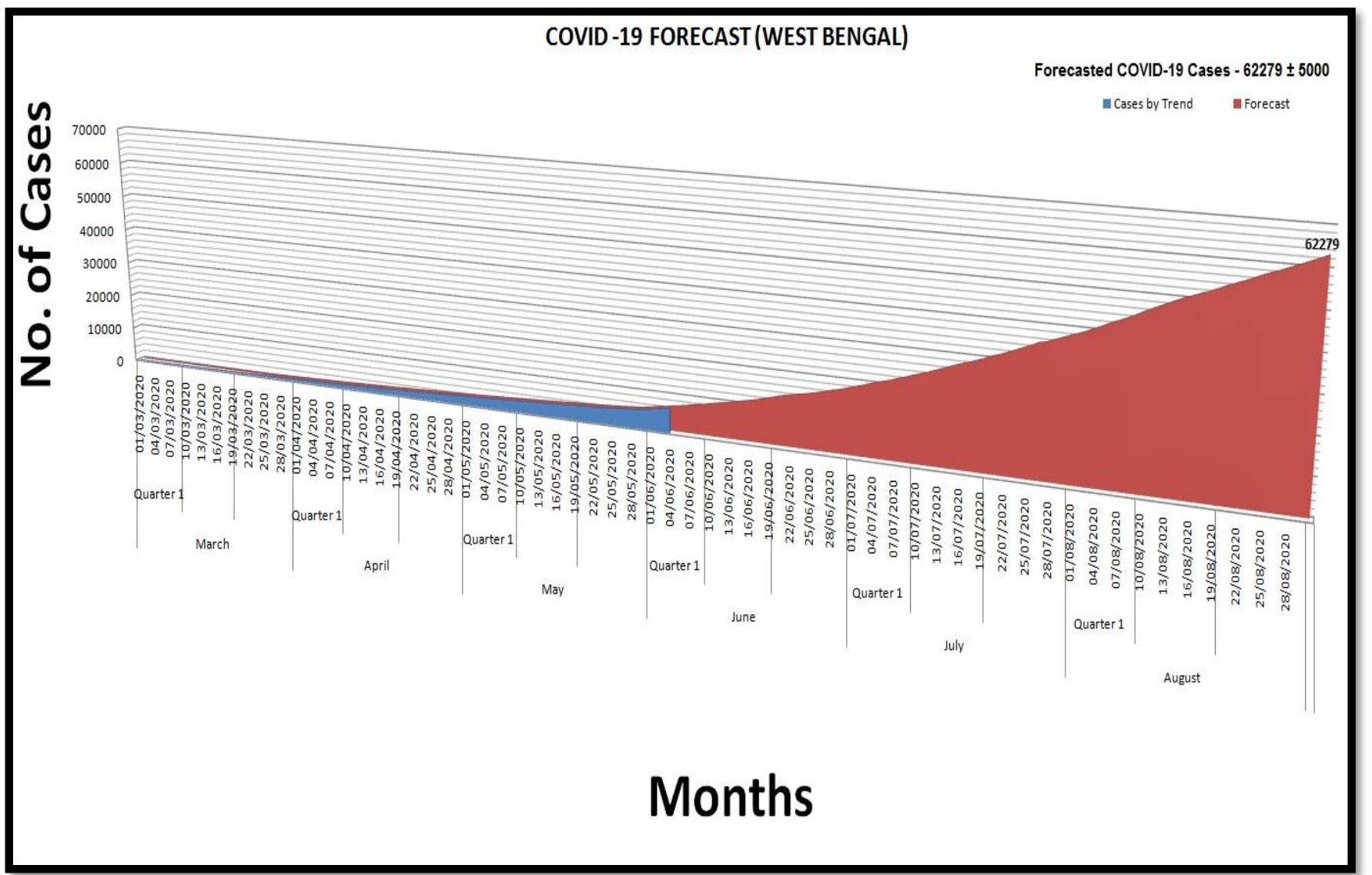

Fig.- COVID - 19 Forecast For the month of July \& August Estimated Cases - 62279 \pm 5000 
District - wise Confirmed cases data** in West Bengal :

\begin{tabular}{|c|c|c|c|c|}
\hline District & Cnfrmd $\triangle$ & Actv & Revrd & Desd \\
\hline Jhargram & 6 & 0 & 6 & 0 \\
\hline Kalimpong & 9 & 2 & 6 & 1 \\
\hline Alipurduar & 12 & 12 & 0 & 0 \\
\hline Jalpaiguri & 18 & 14 & 4 & 0 \\
\hline Purulia & 19 & 19 & 0 & 0 \\
\hline Dakshin Dinajpur & 44 & 26 & 18 & 0 \\
\hline Darjeeling & 60 & 48 & 10 & 2 \\
\hline Other State & 60 & 41 & 16 & 3 \\
\hline Paschim Bardhaman & 66 & 36 & 28 & 2 \\
\hline Paschim Medinipur & 70 & 41 & 28 & 1 \\
\hline Bankura & 95 & 62 & 33 & 0 \\
\hline Murshidabad & 108 & 32 & 74 & 2 \\
\hline Nadia & 110 & 87 & 22 & 1 \\
\hline Purba Bardhaman & 112 & 50 & 62 & 0 \\
\hline Purba Medinipur & 125 & 68 & 56 & 1 \\
\hline Cooch Behar & 138 & 112 & 26 & 0 \\
\hline Malda & 158 & 74 & 84 & 0 \\
\hline Uttar Dinajpur & 173 & 22 & 151 & 0 \\
\hline Birbhum & 181 & 74 & 106 & 1 \\
\hline South 24 Parganas & 221 & 122 & 92 & 7 \\
\hline Hooghly & 429 & 253 & 165 & 11 \\
\hline North 24 Parganas & 910 & 545 & 318 & 47 \\
\hline Howrah & 1,264 & 755 & 467 & 42 \\
\hline Kolkata & 2,488 & 1,258 & 996 & 234 \\
\hline
\end{tabular}

** Data is taken from West Bengal Govt. COVID-19 Website (till $4^{\text {th }}$ June 2020) 


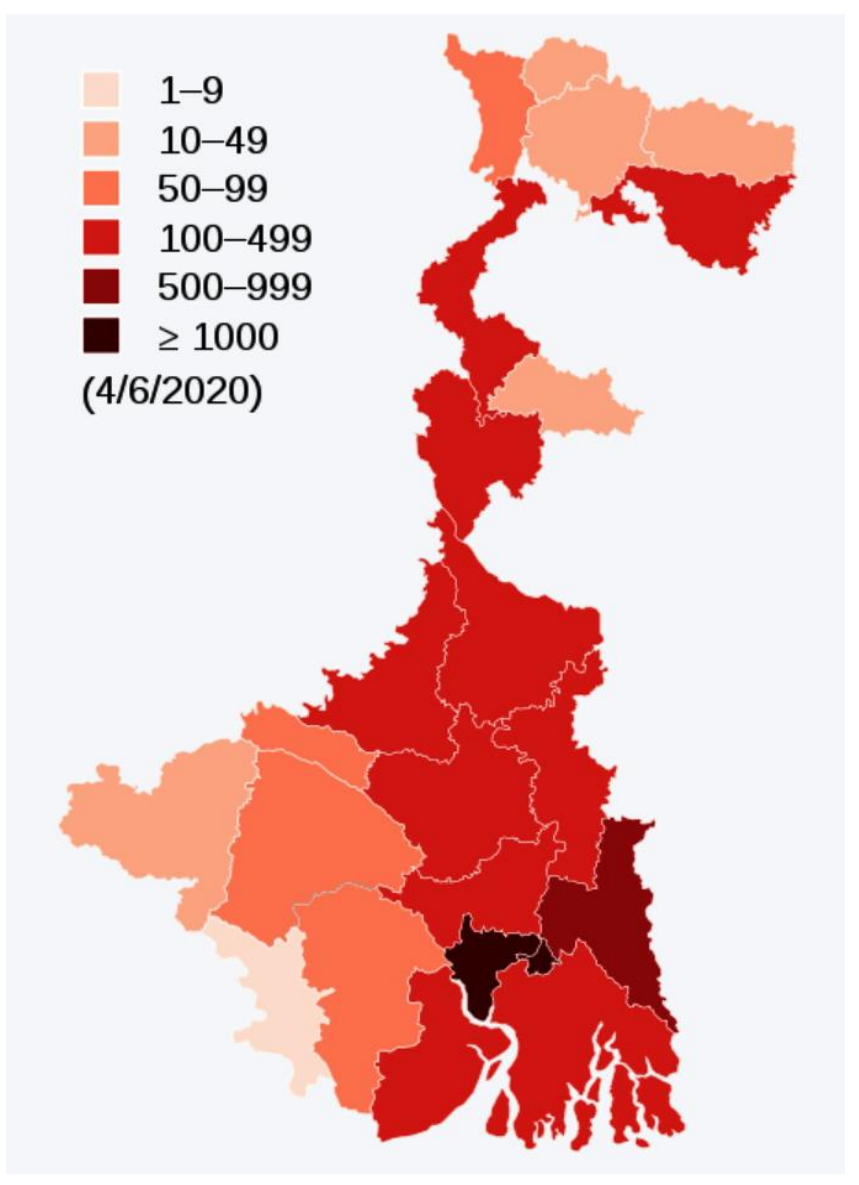

Fig: Map of Districts with Confirmed Cases

\section{Top Districts Affected With COVID-19 in West Bengal :}

\section{Top districts}

\section{2,488 Kolkata}

1,264 Howrah

$910 \begin{aligned} & \text { North } 24 \\ & \text { Parganas }\end{aligned}$

429 Hooghly

\section{$221 \begin{aligned} & \text { South } 24 \\ & \text { Parganas }\end{aligned}$}

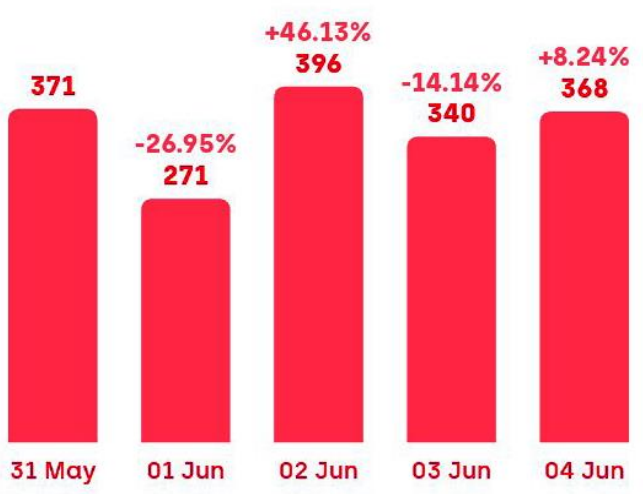

** Data is taken from West Bengal Govt. COVID-19 Website (till $4^{\text {th }}$ June 2020) 
medRxiv preprint doi: https://doi.org/10.1101/2020.06.06.20124180; this version posted June 8, 2020. The copyright holder for this preprint (which was not certified by peer review) is the author/funder, who has granted medRxiv a license to display the preprint in perpetuity.

\section{Kolkata's Covid-19 Figure: A Case Study}
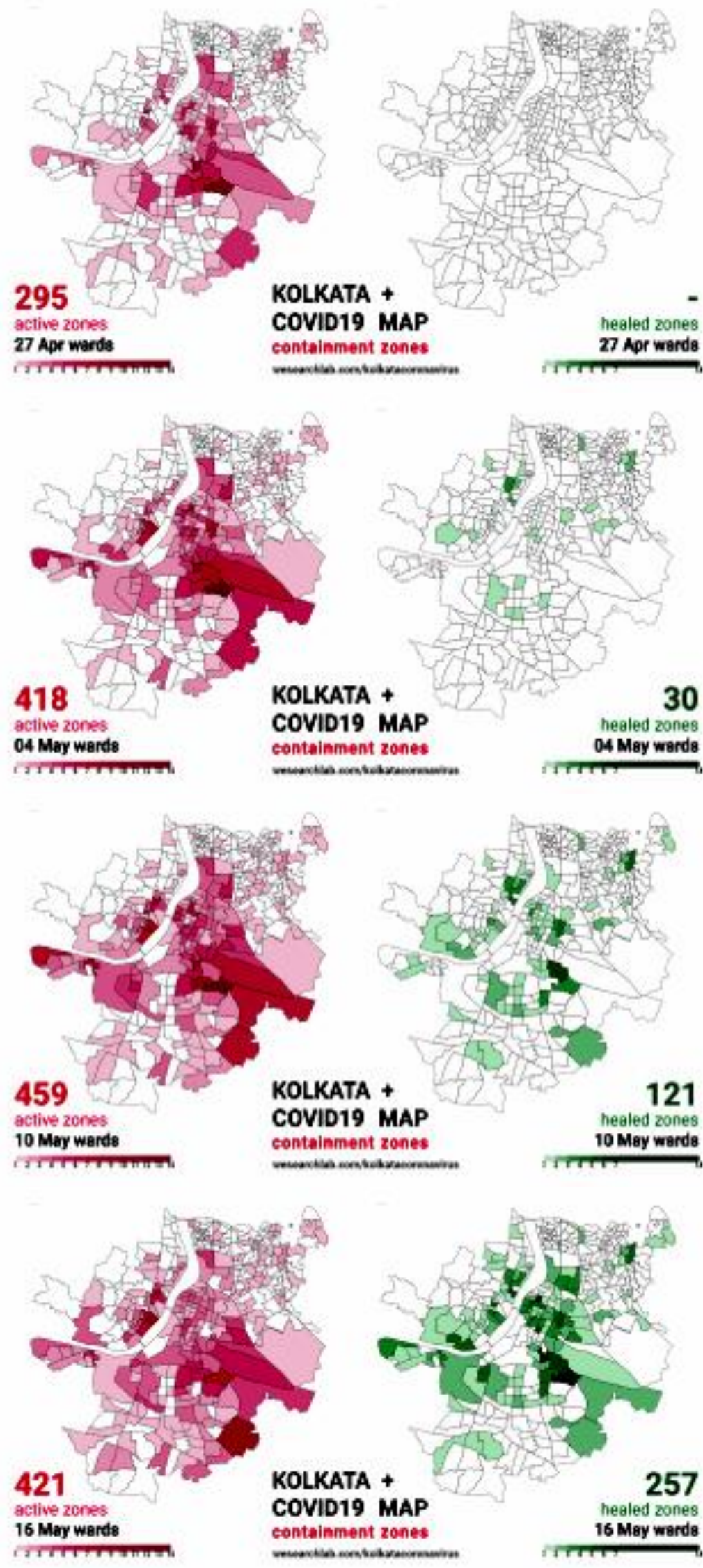

Kolkata's COVID-19

containment zones

The centre has identified 170 COVID-19, hotspot districts in 25 states across India. The states have been asked to classify hotspot areas as red zones and focus on converting the red zones to orange and then green zones.

The West Bengal government on Monday released a list, saying four districts, including

Kolkata, have been declared as red zones in the wake of the COVID-19 outbreak, and 348 areas as containment zones ${ }^{2}$ out of which Kolkata has 227. There are some districts in Orange \& Green zones. The lockdown process will be strict in those Red Zone Containment areas. Some relaxation will be given to Orange zones and most relaxation will be given to Green Zones.

The West Bengal government has been sharing regular updates of the lists of containment zones from $4^{\text {th }}$ May 2020. 
medRxiv preprint doi: https://doi.org/10.1101/2020.06.06.20124180; this version posted June 8, 2020. The copyright holder for this preprint (which was not certified by peer review) is the author/funder, who has granted medRxiv a license to display the preprint in perpetuity. It is made available under a CC-BY-NC-ND 4.0 International license .

COVID-19 Pandemic Data in West Bengal:

West Bengal

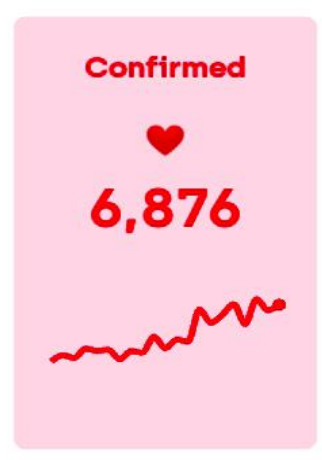

West Bengal
Tested

$2,41,831$

As of 04 June per source

Deceased

355

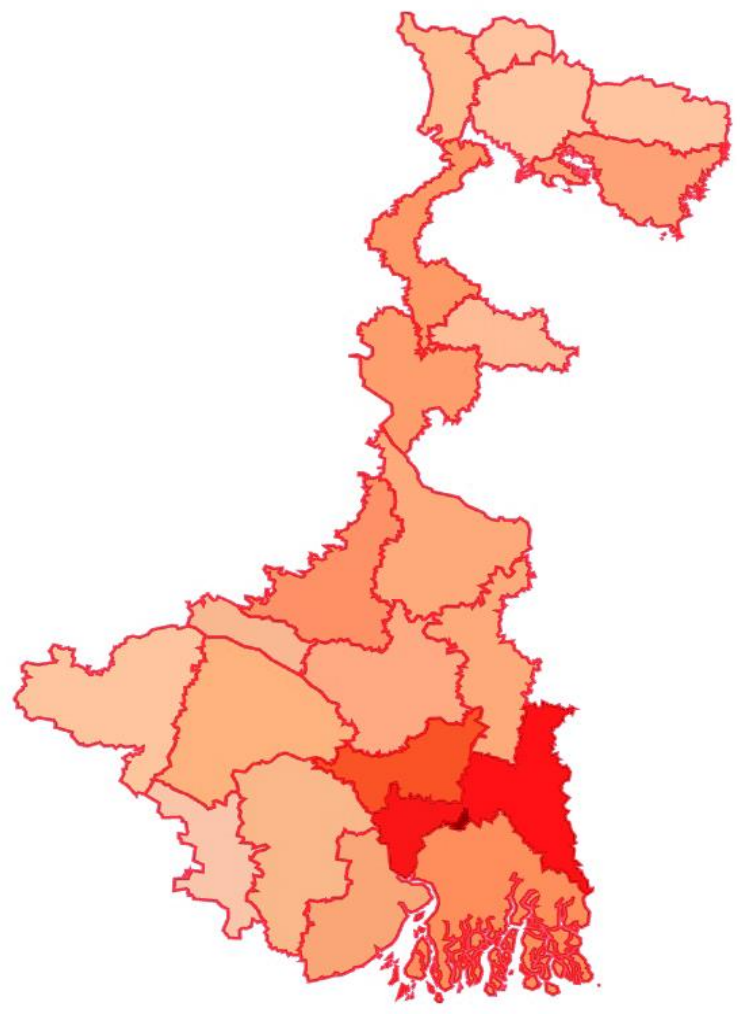

Confirmed cases

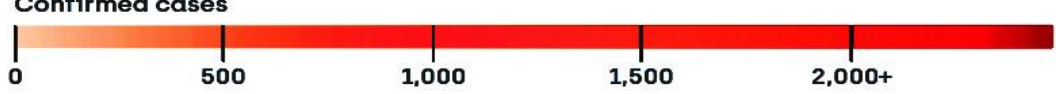

Population

$9,69,06,000$
(2) Based on 2019 population projection by NCP report 
medRxiv preprint doi: https://doi.org/10.1101/2020.06.06.20124180; this version posted June 8, 2020. The copyright holder for this preprint (which was not certified by peer review) is the author/funder, who has granted medRxiv a license to display the preprint in perpetuity.

Confirmed Per Million, Active, Recovery Rate, Mortality Rate, Average Growth Rate, Tests Per Million:

Confirmed Per Million

70.96

India has 172.29 CPM

71 out of every

1 million people in West Bengal have tested positive for the virus.

Recovery Rate (i) $40.26 \%$

For every 100 confirmed cases, 40 have recovered from the virus.

Avg. Growth

Rate

(i)

$6 \%$

29 May - 05 Jun

In the last one week, the number of new infections has grown by an average of $6 \%$ every day.
Active

()

\section{$54.58 \%$}

For every 100 confirmed cases, 55 are currently infected.

Mortality Rate (i)

\section{$5.16 \%$}

For every 100 confirmed cases, 5 have unfortunately passed away from the virus.

Tests Per Million

$\approx 2,496$

As of 1 day ago

For every 1 million people in West Bengal, 2,496 people were tested. 
medRxiv preprint doi: https://doi.org/10.1101/2020.06.06.20124180; this version posted June 8, 2020. The copyright holder for this preprint (which was not certified by peer review) is the author/funder, who has granted medRxiv a license to display the preprint in perpetuity. It is made available under a CC-BY-NC-ND 4.0 International license .

Spread Trends of COVID-19 IN West Bengal:

\section{Spread Trends}
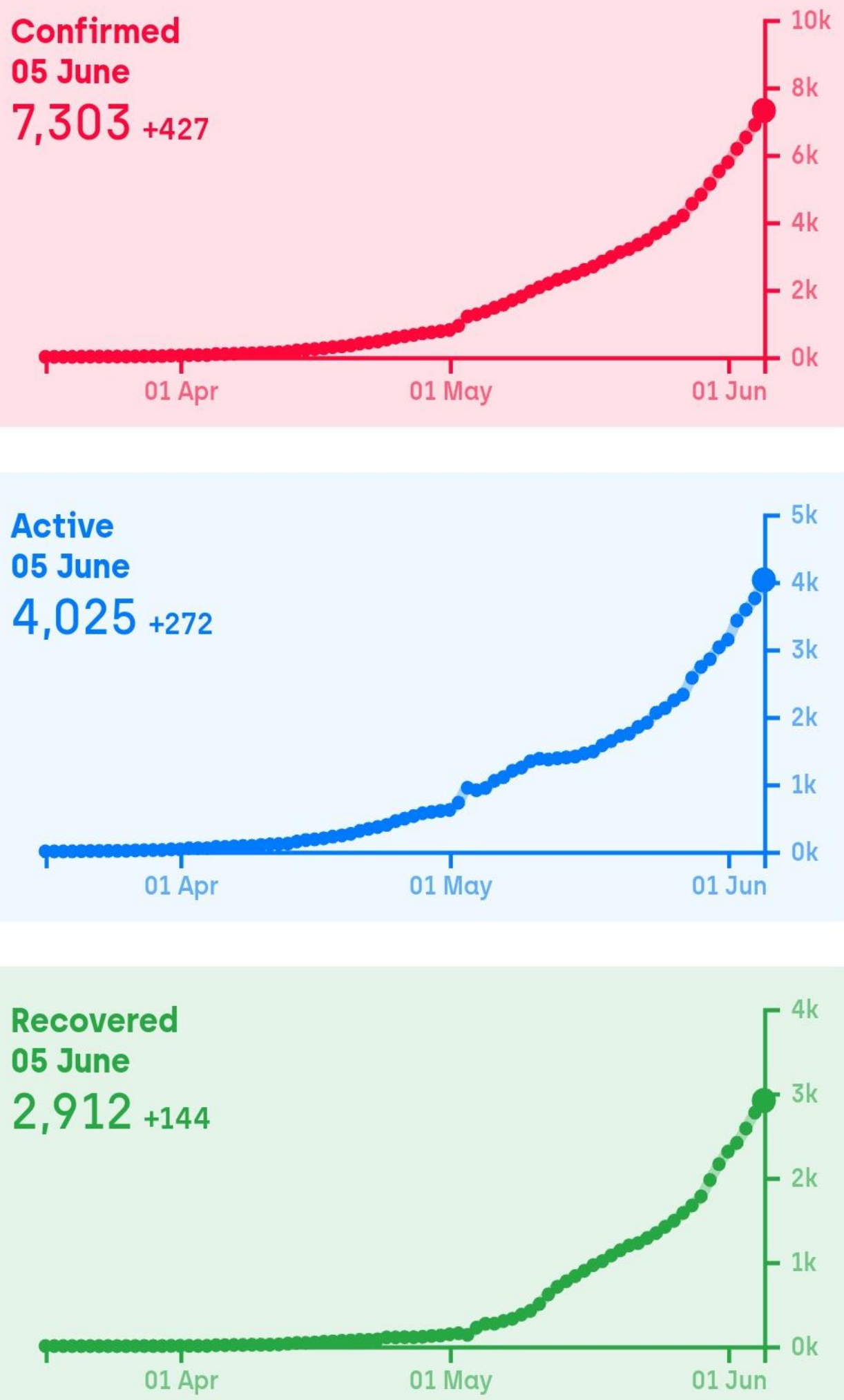
medRxiv preprint doi: https://doi.org/10.1101/2020.06.06.20124180; this version posted June 8, 2020. The copyright holder for this preprint (which was not certified by peer review) is the author/funder, who has granted medRxiv a license to display the preprint in perpetuity. It is made available under a CC-BY-NC-ND 4.0 International license.
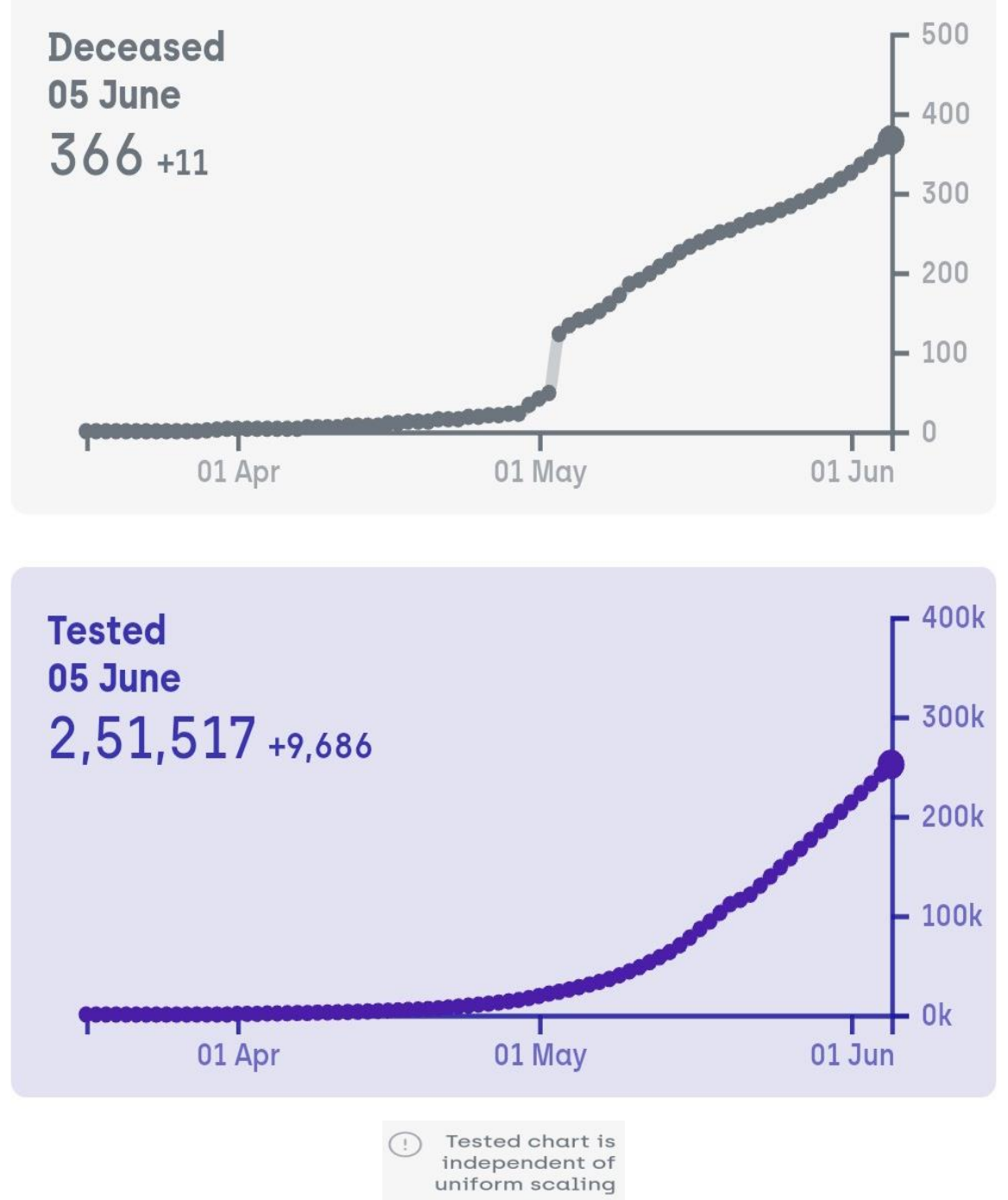

Fig: Spread Trends of COVID-19 IN West Bengal

\section{COVID-19 Cases** in INDIA:}

Confirmed

$+2,918$
Active

Recovered

$+1,438$

$1,09,892$

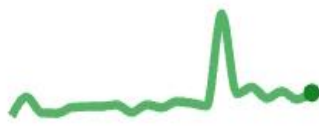

Deceased

$+18$

6,381
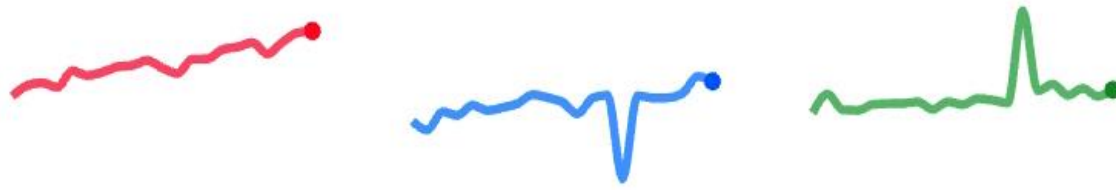

** Data is taken from West Bengal Govt. COVID-19 Website (till $5^{\text {th }}$ June 2020) 


\section{Department of Health \& Family Welfare Govt. of West Bengal}

\section{WEST BENGAL COVID-19 HEALTH BULLETIN}

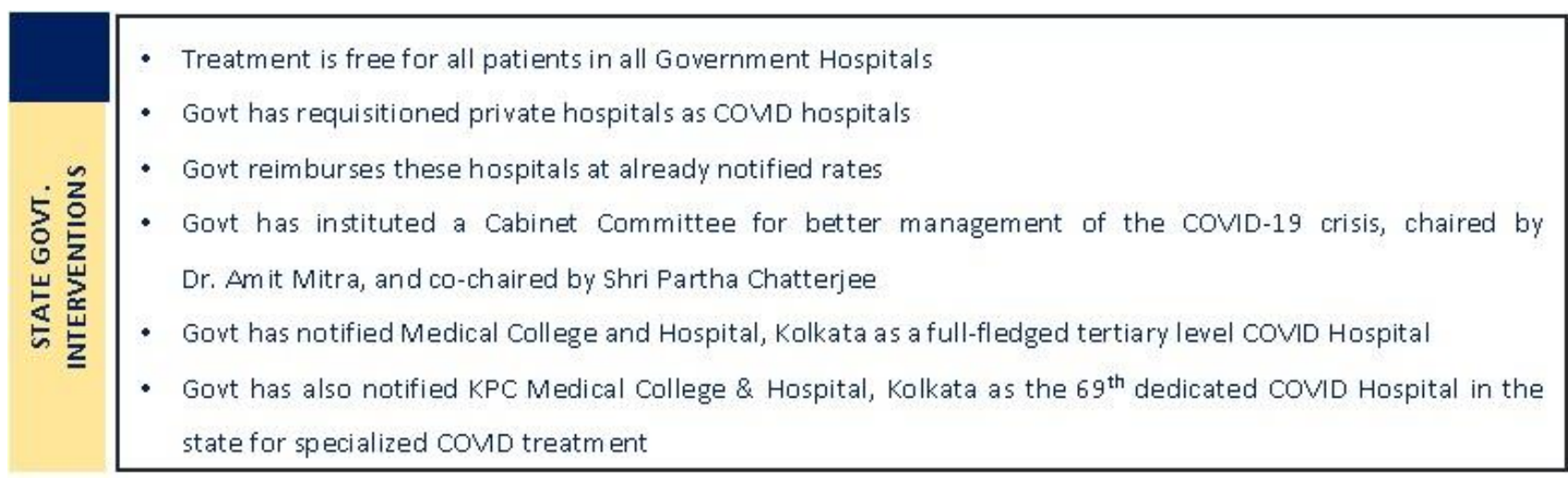

Fig: State Govt. Interventions for COVID-19.

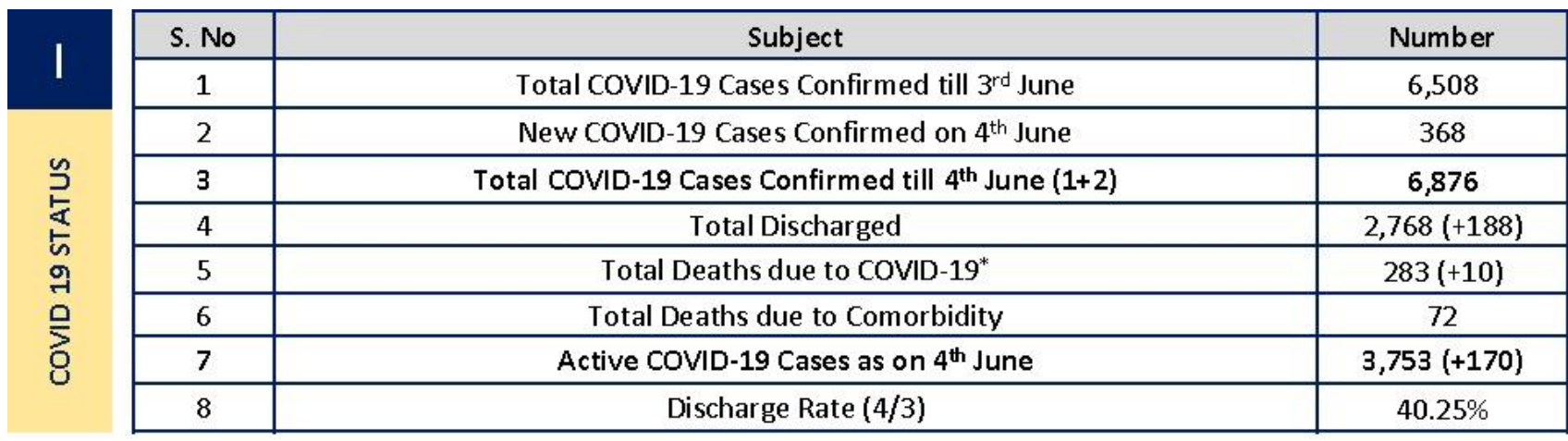

Fig: COVID-19 Status in West Bengal.

\begin{tabular}{|c|c|c|c|}
\hline 11 & S. No & Subject & Number \\
\hline$\|$ & 1 & Samples Tested till $3^{\text {rd }}$ June & $2,32,225$ \\
\hline \multirow{7}{*}{ 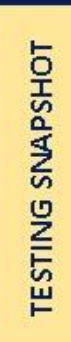 } & 2 & Samples Tested on $4^{\text {th }}$ June & 9,606 \\
\hline & 3 & Total Number of Samples Tested till $4^{\text {th }}$ June $(1+2)$ & $2,41,831$ \\
\hline & 4 & $\begin{array}{l}\text { Tests per Million population } \\
\end{array}$ & 2,687 \\
\hline & 5 & $\%$ of Positive Cases out of Samples Tested & $2.84 \%$ \\
\hline & 6 & Total Testing Laboratories ${ }^{*}$ & 42 \\
\hline & 7 & Testing Laboratories added this week & 2 \\
\hline & 8 & Testing Laboratories pending approval & 1 \\
\hline
\end{tabular}


medRxiv preprint doi: https://doi.org/10.1101/2020.06.06.20124180; this version posted June 8, 2020. The copyright holder for this preprint (which was not certified by peer review) is the author/funder, who has granted medRxiv a license to display the preprint in perpetuity.

It is made available under a CC-BY-NC-ND 4.0 International license .

Fig: Sample Testing Stats for COVID-19.

\begin{tabular}{|c|c|c|c|}
\hline$\|$ & S. No & Subject & Number \\
\hline II & 1 & Total Number of Hospitals dedicated for treating COVID-19 & 69 \\
\hline \multirow{6}{*}{ 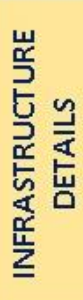 } & 2 & Total Number of Govt. Hospitals dedicated for treating COVID-19 & 16 \\
\hline & 3 & Total Number of Pvt. Hospitals requisitioned for treating COVID-19 & 53 \\
\hline & 4 & Total Number of earmarked COVID-19 Beds & 8,785 \\
\hline & 5 & $\%$ Occupancy in COVID Beds & $20.14 \%$ \\
\hline & 6 & Total ICU Beds in the COVID Hospitals & 920 \\
\hline & 7 & Total Number of Ventilators in the COVID Hospitals & 392 \\
\hline
\end{tabular}

Fig: Healthcare Infrastructure for COVID-19.

\begin{tabular}{|c|c|c|c|}
\hline IV & \multicolumn{3}{|c|}{ Institutional Quarantine } \\
\hline & 1 & Total Govt. Quarantine Centres & 582 \\
\hline \multirow{10}{*}{ 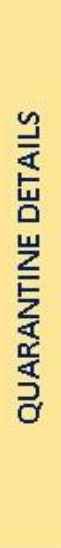 } & 2 & Total number of people in Govt. Quarantine Centres & 20,662 \\
\hline & 3 & Total number of people released from Govt. Quarantine Centres & 57,940 \\
\hline & \multicolumn{3}{|c|}{ Home Quarantine } \\
\hline & 1 & Total Home Quarantined People & $2,46,981$ \\
\hline & 2 & Total number of people currently in Home Quarantine & $1,48,359$ \\
\hline & 3 & Total number of people released from Home Quarantine Centres & 98,622 \\
\hline & \multicolumn{3}{|c|}{ Quarantine for Migrant Returnees* } \\
\hline & 1 & Total Quarantine Facilities & 11,205 \\
\hline & 2 & Total number of returnees in Quarantine Centres & $1,36,600$ \\
\hline & 3 & Total number of workers released from Quarantine Centres & 40,980 \\
\hline
\end{tabular}

Fig: Quarantine Details for COVID-19.

\section{Allegations against West Bengal Government: A Case Study}

Chief Minister of West Bengal Mamata Banerjee and her government was widely criticized of the handling of the coronavirus pandemic and was accused of concealing facts by the opposition and critics. The opposition accused Mamata of playing "appeasement politics" amid the COVID-19 crisis. On 1 April, Banerjee claimed that the West Bengal Government have already traced 54 people who attended the Tablighi Jamaat religious gathering during the COVID-19 Outbreak, and 44 of them are foreigners. Although according to a report by central security agencies, 232 people had attended the Delhi's Tablighi Jamaat event from West Bengal.

Of this, 123 are Indian nationals and 109 are foreigners.

Sooner she clarified that her government has acted swiftly after the Nizamuddin area was declared as a hotspot where nearly 2,300 people were staying despite the lockdown.

She further added that the government has quarantined 177 people, including 108 foreigners, who attended the Tablighi Jamaat congregation at the Nizamuddin Markaz. 
medRxiv preprint doi: https://doi.org/10.1101/2020.06.06.20124180; this version posted June 8, 2020. The copyright holder for this preprint (which was not certified by peer review) is the author/funder, who has granted medRxiv a license to display the preprint in perpetuity.

It is made available under a CC-BY-NC-ND 4.0 International license .

The West Bengal Government has been also criticized for not sending enough samples to the National Institute of Cholera and Enteric Diseases(NICED) for testing.

West Bengal test numbers saw some rise after talks between government and NICED.

According to them, this will be scaled up further in coming days.

The West Bengal Government has also been recommended to ensure transparency, genuine and verifiable data of COVID-19 by the West Bengal Doctors Forum (WBDF), as doctors cannot afford to send wrong signals to the world.

The doctors also hit out at the idea of the bureaucratic system to identify the death of COVID-19 patients. Their spokesperson claimed that every doctor is qualified enough and does not need a committee for such certification. On April 25, 2020,

The WB Govt admitted that 57 COVID-19 patients died but also said that 39 from comorbidities, after Inter Ministerial Central Team (IMCT) seek report.

The IMCT also pointed out flaws of the Govt in their letter to the Chief Secretary Rajiva Sinha, in which the letter read:

There were a large number of patients in the isolation wards of Chittaranjan National Cancer Institute (CNCI) as well as MR Bangur hospitals awaiting COVID test results for five days or longer.

Specifically at CNCI, there were four patients awaiting test result since April 16, 2020, two patients awaiting test result since April 17, 2020, and three since April 18, 2020.

Some of the patients have tested negative. It is not clear why the test results should take such a long time and there is a danger of COVID-19 negative patient acquiring the infection in the hospital while awaiting test result

\section{Discussion\& Conclusion:}

The world is going through a pandemic, and almost every country is affected by it. A country as well as the States needs to know how much burden of active and confirmed cases it will have to bear in the coming time. It will help the states in taking pre-active measures to prepare adequate health infrastructure for the coming time based on future needs. We used ARIMA model and Auto ARIMA model on the time series data of COVID-19 cases in West Bengal for forecasting the total confirmed and active cases till August end.

Based on the forecasts, confirmed cases for West Bengal at the end of June are expected to be 1783818724 (95\% CI: 128806, 227968). West Bengal will be having 27147-30616 confirmed cases (95\% CI: $173917,415800)$ in the mid of July from the estimates, Even West Bengal will be having 50588-55617 confirmed cases (95\% CI: 198917, 525800) in the mid of August from the estimates \& we expect that India will be having

Estimated Cases $-\mathbf{6 2 2 7 9} \pm \mathbf{5 0 0 0}$ at the end of August.

These results also show that daily confirmed cases are increasing at a faster pace even at the end of June with around 400-500 daily confirmed cases, so it is likely that peak will be attained afterwards.

According to our forecasts, it is a very alarming situation for India \& West Bengal in coming days.

However, the actual numbers can go higher than our estimates of confirmed cases, active cases $\&$ trends we made based on the data till June 3rd in this forecast, when West Bengal observed complete lockdown. Currently,

West Bengal has a partial lockdown or Following Unlock 1.0 with restrictions varying for three zones (red, orange and green zone) based on the current assessment of the situation in there.

Lockdown is getting lifted, and in this case, there will be a surge in the number of daily confirmed and active cases. 
medRxiv preprint doi: https://doi.org/10.1101/2020.06.06.20124180; this version posted June 8, 2020. The copyright holder for this preprint (which was not certified by peer review) is the author/funder, who has granted medRxiv a license to display the preprint in perpetuity.

It is made available under a CC-BY-NC-ND 4.0 International license .

The requirement of isolation beds, ICUs and ventilators will also be increased in that scenario. The migrants are returning to their homes due to loss of livelihood and income in the lockdown period, which may lead to a rise in the number of cases, and could not be accounted for, in our projections.

So, India and its majorly affected states like Maharashtra, Gujarat, Tamil Nadu and Delhi \& West Bengal need to be well prepared for the pandemic challenge in coming time and focus on increasing their healthcare infrastructure, and other states should also remain alert till the pandemic completely recedes. We suggest a Public-Private Partnership (PPP) model in the health sector to accommodate COVID-19 patients adequately and reduce the burden of the already overstretched Indian public health care system.

\section{Limitations or Errors that may occur:}

The forecasting of COVID-19 cases is done based on the data under the lockdown duration and few in Unlock 1.0. So, the forecasted cases in future will be showing the same trend as India would have observed, had it been observing complete lockdown.

Since May 4, India is observing Unlock 1.0, and for that actual cases will/can/may be more than the forecasted cases. For our state it is showing hike in COVID-19 infection and increased trend in future, but the situation may not occur in future because of the nature of the previous trend-pattern is different from now.

Forecasted cases based on ARIMA model in our study for some states having lower bound for the $95 \%$ CI comes negative values which we have considered zero cases in that situation. In our study, the seasonality factor was considered but it may vary now due to Unlock 1.0, and it may affect our Forecast,

Therefore the is a Plus - Minus in the forecasted cases to avoid any Big Error, \& make the Data more Reliable.

Table : Date wise number confirmed and active cases in West Bengal , Trend , Predicted

\begin{tabular}{|c|c|c|c|c|c|c|c|c|c|}
\hline & & & $Y t$ & & $Y t / C M A$ & $\begin{array}{l}\text { Average (respective } \\
\text { quature) }\end{array}$ & $\begin{array}{l}\text { De- } \\
\text { Seasonalized } \\
\text { Value } \\
\end{array}$ & \multicolumn{2}{|c|}{$\begin{array}{l}\text { Intersept }+ \text { Slope } * \text { Time } \\
\text { Code }\end{array}$} \\
\hline No. & Months & Date & Cases & $\begin{array}{l}\text { Moving Average } \\
\text { (5) MA }\end{array}$ & $S t * I t$ & $S t$ & $\mathbf{Y t} / \mathrm{St}$ & Trend & $\begin{array}{l}\text { Predicted } \\
(Y p)\end{array}$ \\
\hline 1 & March & $01 / 03 / 2020$ & 0 & & 0.00 & 0.00 & 0.00 & -0.59 & 0 \\
\hline 2 & & $02 / 03 / 2020$ & 0 & 0.00 & 0.00 & 0.00 & 0.00 & 0.06 & 0 \\
\hline 3 & & $03 / 03 / 2020$ & 0 & 0.00 & 0.00 & 0.00 & 0.00 & 0.71 & 0 \\
\hline 4 & & $04 / 03 / 2020$ & 0 & 0.00 & 0.00 & 0.00 & 0.00 & 1.35 & 1 \\
\hline 5 & & $05 / 03 / 2020$ & 0 & 0.00 & 0.00 & 0.00 & 0.00 & 2.00 & 1 \\
\hline 6 & & $06 / 03 / 2020$ & 0 & 0.00 & 0.00 & 0.00 & 0.00 & 2.65 & 2 \\
\hline 7 & & $07 / 03 / 2020$ & 0 & 0.00 & 0.00 & 0.00 & 0.00 & 3.30 & 3 \\
\hline 8 & & $08 / 03 / 2020$ & 0 & 0.00 & 0.00 & 0.00 & 0.00 & 3.95 & 4 \\
\hline 9 & & $09 / 03 / 2020$ & 0 & 0.00 & 0.00 & 0.00 & 0.00 & 4.59 & 5 \\
\hline 10 & & $10 / 03 / 2020$ & 0 & 0.00 & 0.00 & 0.00 & 0.00 & 5.24 & 6 \\
\hline 11 & & $11 / 03 / 2020$ & 0 & 0.00 & 0.00 & 0.00 & 0.00 & 5.89 & 7 \\
\hline 12 & & $12 / 03 / 2020$ & 0 & 0.00 & 0.00 & 0.00 & 0.00 & 6.54 & 9 \\
\hline
\end{tabular}


medRxiv preprint doi: https://doi.org/10.1101/2020.06.06.20124180; this version posted June 8, 2020. The copyright holder for this preprint

(which was not certified by peer review) is the author/funder, who has granted medRxiv a license to display the preprint in perpetuity.

It is made available under a CC-BY-NC-ND 4.0 International license.

\begin{tabular}{|c|c|c|c|c|c|c|c|c|c|}
\hline 13 & & $13 / 03 / 2020$ & 0 & 0.00 & 0.00 & 0.00 & 0.00 & 7.18 & 11 \\
\hline 14 & & $14 / 03 / 2020$ & 0 & 0.00 & 0.00 & 0.60 & 0.00 & 7.83 & 12 \\
\hline 15 & & $15 / 03 / 2020$ & 0 & 0.00 & 0.00 & 1.00 & 0.00 & 8.48 & 14 \\
\hline 16 & & $16 / 03 / 2020$ & 0 & 0.00 & 0.00 & 1.36 & 0.00 & 9.13 & 16 \\
\hline 17 & & $17 / 03 / 2020$ & 0 & 0.00 & 0.00 & 1.70 & 0.00 & 9.78 & 18 \\
\hline 18 & & $18 / 03 / 2020$ & 1 & 0.33 & 3.00 & 2.08 & 0.48 & 10.42 & 21 \\
\hline 19 & & $19 / 03 / 2020$ & 2 & 1.00 & 2.00 & 1.82 & 1.10 & 11.07 & 23 \\
\hline 20 & & $20 / 03 / 2020$ & 3 & 1.67 & 1.80 & 1.72 & 1.74 & 11.72 & 25 \\
\hline 21 & & $21 / 03 / 2020$ & 4 & 2.33 & 1.71 & 1.68 & 2.38 & 12.37 & 28 \\
\hline 22 & & $22 / 03 / 2020$ & 7 & 3.67 & 1.91 & 1.70 & 4.13 & 13.02 & 31 \\
\hline 23 & & $23 / 03 / 2020$ & 9 & 5.33 & 1.69 & 1.63 & 5.51 & 13.66 & 34 \\
\hline 24 & & $24 / 03 / 2020$ & 9 & 6.00 & 1.50 & 1.62 & 5.56 & 14.31 & 37 \\
\hline 25 & & $25 / 03 / 2020$ & 10 & 6.33 & 1.58 & 1.63 & 6.12 & 14.96 & 40 \\
\hline 26 & & $26 / 03 / 2020$ & 15 & 8.33 & 1.80 & 1.65 & 9.10 & 15.61 & 43 \\
\hline 27 & & $27 / 03 / 2020$ & 17 & 10.67 & 1.59 & 1.63 & 10.40 & 16.26 & 47 \\
\hline 28 & & $28 / 03 / 2020$ & 20 & 12.33 & 1.62 & 1.63 & 12.29 & 16.90 & 50 \\
\hline 29 & & $29 / 03 / 2020$ & 22 & 14.00 & 1.57 & 1.62 & 13.54 & 17.55 & 54 \\
\hline 30 & & $30 / 03 / 2020$ & 27 & 16.33 & 1.65 & 1.64 & 16.50 & 18.20 & 58 \\
\hline 31 & April & $01 / 04 / 2020$ & 37 & 21.33 & 1.73 & 1.62 & 22.85 & 18.85 & 62 \\
\hline 32 & & $02 / 04 / 2020$ & 40 & 25.67 & 1.56 & 1.59 & 25.17 & 19.49 & 66 \\
\hline 33 & & $03 / 04 / 2020$ & 46 & 28.67 & 1.60 & 1.60 & 28.78 & 20.14 & 70 \\
\hline 34 & & $04 / 04 / 2020$ & 55 & 33.67 & 1.63 & 1.58 & 34.79 & 20.79 & 75 \\
\hline 35 & & $05 / 04 / 2020$ & 60 & 38.33 & 1.57 & 1.57 & 38.21 & 21.44 & 79 \\
\hline 36 & & $06 / 04 / 2020$ & 67 & 42.33 & 1.58 & 1.57 & 42.62 & 22.09 & 84 \\
\hline 37 & & $07 / 04 / 2020$ & 77 & 48.00 & 1.60 & 1.56 & 49.22 & 22.73 & 88 \\
\hline 38 & & $08 / 04 / 2020$ & 79 & 52.00 & 1.52 & 1.55 & 51.08 & 23.38 & 93 \\
\hline 39 & & $09 / 04 / 2020$ & 88 & 55.67 & 1.58 & 1.56 & 56.31 & 24.03 & 98 \\
\hline 40 & & $10 / 04 / 2020$ & 97 & 61.67 & 1.57 & 1.56 & 62.24 & 24.68 & 103 \\
\hline 41 & & $11 / 04 / 2020$ & 103 & 66.67 & 1.55 & 1.56 & 66.15 & 25.33 & 109 \\
\hline 42 & & $12 / 04 / 2020$ & 105 & 69.33 & 1.51 & 1.56 & 67.17 & 25.97 & 114 \\
\hline 43 & & $13 / 04 / 2020$ & 120 & 75.00 & 1.60 & 1.61 & 74.30 & 26.62 & 120 \\
\hline 44 & & $14 / 04 / 2020$ & 130 & 83.33 & 1.56 & 1.61 & 80.71 & 27.27 & 125 \\
\hline 45 & & $15 / 04 / 2020$ & 142 & 90.67 & 1.57 & 1.61 & 88.07 & 27.92 & 131 \\
\hline 46 & & $16 / 04 / 2020$ & 157 & 99.67 & 1.58 & 1.63 & 96.57 & 28.56 & 137 \\
\hline 47 & & $17 / 04 / 2020$ & 227 & 128.00 & 1.77 & 1.62 & 139.73 & 29.21 & 243 \\
\hline 48 & & $18 / 04 / 2020$ & 252 & 159.67 & 1.58 & 1.58 & 159.23 & 29.86 & 249 \\
\hline 49 & & $19 / 04 / 2020$ & 276 & 176.00 & 1.57 & 1.59 & 173.86 & 30.51 & 298 \\
\hline 50 & & $20 / 04 / 2020$ & 330 & 202.00 & 1.63 & 1.59 & 207.45 & 31.16 & 362 \\
\hline 51 & & $21 / 04 / 2020$ & 362 & 230.67 & 1.57 & 1.58 & 229.77 & 31.80 & $\overline{416}$ \\
\hline 52 & & $22 / 04 / 2020$ & 394 & 252.00 & 1.56 & 1.57 & 250.61 & 32.45 & 471 \\
\hline 53 & & $23 / 04 / 2020$ & 452 & 282.00 & 1.60 & 1.57 & 287.71 & 33.10 & 518 \\
\hline 54 & & $24 / 04 / 2020$ & 506 & 319.33 & 1.58 & 1.56 & 324.89 & 33.75 & 559 \\
\hline 55 & & $25 / 04 / 2020$ & 546 & 350.67 & 1.56 & 1.55 & 352.76 & 34.40 & 596 \\
\hline 56 & & $26 / 04 / 2020$ & 586 & 377.33 & 1.55 & 1.55 & 378.26 & 35.04 & 603 \\
\hline
\end{tabular}


medRxiv preprint doi: https://doi.org/10.1101/2020.06.06.20124180; this version posted June 8, 2020. The copyright holder for this preprint (which was not certified by peer review) is the author/funder, who has granted medRxiv a license to display the preprint in perpetuity.

It is made available under a CC-BY-NC-ND 4.0 International license.

\begin{tabular}{|c|c|c|c|c|c|c|c|c|c|}
\hline 57 & & $27 / 04 / 2020$ & 633 & 406.33 & 1.56 & 1.55 & 409.51 & 35.69 & 659 \\
\hline 58 & & $28 / 04 / 2020$ & 663 & 432.00 & 1.53 & 1.56 & 425.99 & 36.34 & 698 \\
\hline 59 & & $29 / 04 / 2020$ & 696 & 453.00 & 1.54 & 1.59 & 438.16 & 36.99 & 708 \\
\hline 60 & & $30 / 04 / 2020$ & 758 & 484.67 & 1.56 & 1.59 & 477.14 & 37.64 & 783 \\
\hline 61 & May & $01 / 05 / 2020$ & 795 & 517.67 & 1.54 & 1.59 & 501.38 & 38.28 & 841 \\
\hline 62 & & $02 / 05 / 2020$ & 922 & 572.33 & 1.61 & 1.59 & 579.70 & 38.93 & 949 \\
\hline 63 & & $03 / 05 / 2020$ & 1198 & 706.67 & 1.70 & 1.58 & 759.43 & 39.58 & 1257 \\
\hline 64 & & $04 / 05 / 2020$ & 1259 & 819.00 & 1.54 & 1.55 & 811.98 & 40.23 & 1295 \\
\hline 65 & & $05 / 05 / 2020$ & 1344 & 867.67 & 1.55 & 1.55 & 865.74 & 40.87 & 1374 \\
\hline 66 & & $06 / 05 / 2020$ & 1456 & 933.33 & 1.56 & 1.55 & 936.36 & 41.52 & 1482 \\
\hline 67 & & $07 / 05 / 2020$ & 1548 & 1001.33 & 1.55 & 1.55 & 997.26 & 42.17 & 1591 \\
\hline 68 & & $08 / 05 / 2020$ & 1678 & 1075.33 & 1.56 & 1.55 & 1081.99 & 42.82 & 1699 \\
\hline 69 & & $09 / 05 / 2020$ & 1786 & 1154.67 & 1.55 & 1.55 & 1154.77 & 43.47 & 1788 \\
\hline 70 & & $10 / 05 / 2020$ & 1939 & 1241.67 & 1.56 & 1.54 & 1256.75 & 44.11 & 1887 \\
\hline 71 & & $11 / 05 / 2020$ & 2063 & 1334.00 & 1.55 & 1.54 & 1343.32 & 44.76 & 2124 \\
\hline 72 & & $12 / 05 / 2020$ & 2173 & 1412.00 & 1.54 & 1.53 & 1417.20 & 45.41 & 2362 \\
\hline 73 & & $13 / 05 / 2020$ & 2290 & 1487.67 & 1.54 & 1.53 & 1495.48 & 46.06 & 2456 \\
\hline 74 & & $14 / 05 / 2020$ & 2377 & 1555.67 & 1.53 & 1.53 & 1552.08 & 46.71 & 2552 \\
\hline 75 & & $15 / 05 / 2020$ & 2461 & 1612.67 & 1.53 & 1.53 & 1605.40 & 47.35 & 2648 \\
\hline 76 & & $16 / 05 / 2020$ & 2576 & 1679.00 & 1.53 & 1.53 & 1678.43 & 48.00 & 2746 \\
\hline 77 & & $17 / 05 / 2020$ & 2677 & 1751.00 & 1.53 & 1.53 & 1746.94 & 48.65 & 2845 \\
\hline 78 & & $18 / 05 / 2020$ & 2825 & 1834.00 & 1.54 & 1.53 & 1843.00 & 49.30 & 2946 \\
\hline 79 & & $19 / 05 / 2020$ & 2961 & 1928.67 & 1.54 & 1.53 & 1934.83 & 49.95 & 3047 \\
\hline 80 & & $20 / 05 / 2020$ & 3103 & 2021.33 & 1.54 & 1.53 & 2025.36 & 50.59 & 3151 \\
\hline 81 & & $21 / 05 / 2020$ & 3197 & 2100.00 & 1.52 & 1.53 & 2088.15 & 51.24 & 3255 \\
\hline 82 & & $22 / 05 / 2020$ & 3332 & 2176.33 & 1.53 & 1.53 & 2172.18 & 51.89 & 3361 \\
\hline 83 & & $23 / 05 / 2020$ & 3459 & 2263.67 & 1.53 & 1.53 & 2254.25 & 52.54 & 3468 \\
\hline 84 & & $24 / 05 / 2020$ & 3667 & 2375.33 & 1.54 & 1.54 & 2380.17 & 53.18 & 3576 \\
\hline 85 & & $25 / 05 / 2020$ & 3816 & 2494.33 & 1.53 & 1.54 & 2476.67 & 53.83 & 3885 \\
\hline 86 & & $26 / 05 / 2020$ & 4009 & 2608.33 & 1.54 & 1.54 & 2595.88 & 54.48 & 4096 \\
\hline 87 & & $27 / 05 / 2020$ & 4192 & 2733.67 & 1.53 & 1.55 & 2696.45 & 55.13 & 4265 \\
\hline 88 & & $28 / 05 / 2020$ & 4536 & 2909.33 & 1.56 & 1.56 & 2911.62 & 56.42 & 4637 \\
\hline 89 & & $29 / 05 / 2020$ & 4813 & 3116.33 & 1.54 & 1.55 & 3096.94 & 57.72 & 4953 \\
\hline 90 & & $30 / 05 / 2020$ & 5130 & 3314.33 & 1.55 & 1.55 & 3302.27 & 58.37 & 5247 \\
\hline 91 & June & $01 / 06 / 2020$ & 5772 & 3634.00 & 1.59 & 1.54 & 3738.56 & 60.96 & 5847 \\
\hline 92 & & $02 / 06 / 2020$ & 6168 & 3980.00 & 1.55 & 1.53 & 4023.99 & 63.55 & 6332 \\
\hline 93 & & $03 / 06 / 2020$ & 6508 & 4225.33 & 1.54 & 1.53 & 4261.51 & 68.09 & 6536 \\
\hline 94 & & $04 / 06 / 2020$ & 6876 & 4461.33 & 1.54 & 1.52 & 4521.83 & 72.62 & 6938 \\
\hline 95 & & $05 / 06 / 2020$ & 7303 & 4584.00 & 1.50 & 1.50 & 4584.00 & 75.38 & 7354 \\
\hline
\end{tabular}


medRxiv preprint doi: https://doi.org/10.1101/2020.06.06.20124180; this version posted June 8, 2020. The copyright holder for this preprint (which was not certified by peer review) is the author/funder, who has granted medRxiv a license to display the preprint in perpetuity.

\section{References}

1. Batista M. (2020), Estimation of the final size of the COVID-19 epidemic. MedRxiv. doi:10(2020.02), 16-20023606.

2. Benvenuto D., Giovanetti M., Vassallo L., Angeletti S., Picozzi S. (2020), Application of the ARIMA model on the COVID-2019 epidemic dataset, Data in Brief, 29, 105340. https://doi.org/10.1016/j.dib.2020.105340

3. Chakraborty, T., \& Ghosh, I. (2020). Real-time forecasts and risk assessment of novel coronavirus (COVID-19) cases: A data-driven analysis. Chaos, solitons, and fractals, 135, 109850. Advance online publication. https://doi.org/10.1016/j.chaos.2020.109850

4. Fanelli D., Piazza F. (2020), analysis and forecast of COVID-19 spreading in China, Italy and France, Chaos, Solitons \& Fractals, 134, 109761. https://doi.org/10.1016/j.chaos.2020.109761

5. Kumar P., Kalita H., Patairiya S., Sharma Y. D., Nanda C., Rani M., Rahmai J., Bhagavathula A. S. (2020), Forecasting the dynamics of COVID-19 Pandemic in Top 15 countries in April 2020 through ARIMA Model with Machine Learning Approach. MedRxiv.

6. Gupta R., Pal S. K. (2020), Trend Analysis and Forecasting of COVID-19 outbreak in India. MedRxiv

7. World Population Prospects 2019

https://population.un.org/wpp/Publications/Files/WPP2019_Highlights.pdf

8. Tiwari, S., Kumar, S., \& Guleria, K. (2020). Outbreak Trends of Coronavirus Disease-2019 in India: A Prediction. Disaster medicine and public health preparedness, 1-6. Advance online publication

9. COV-IND-19 Study Group. (2020, May 19). Retrieved from COVID-19 Outbreak in India: https://umich-biostatistics.shinyapps.io/covid19/

10. Singh, R. K., Rani, M., Bhagavathula, A. S., Sah, R., Rodriguez-Morales, A. J., Kalita, H., Nanda, C., Sharma, S., Sharma, Y. D., Rabaan, A. A., Rahmani, J., \& Kumar, P. (2020). Prediction of the COVID-19 Pandemic for the Top 15 Affected Countries: Advanced Autoregressive Integrated Moving Average (ARIMA) Model. JMIR public health and surveillance, 6(2), e19115

11. Wikipedia COVID-19 Pandemic https://20in\%20West\%20Bengal\%20-\%20Wikipedia.html

12. COVID-19 India. (2020, June). Retrieved from Coronavirus Outbreak in India: https://www.covid19india.org

13. Public Health in West Bengal -Current Status and Ongoing Interventions http://wbgovthealth.gov.in

14. West Bengal COVID-19 Bulletin http://wbgovthealth.gov.in

cC) $\$ \begin{aligned} & \text { COVID } 19 \text { Pandemic: A Real-time Forecasts \& Prediction of } \\ & \text { Confirmed Cases, Active Cases using the ARIMA model \& Public } \\ & \text { Health in West Bengal, India. by Dibash Sarkar is licensed under } \\ & \text { CC BY-NC-ND 4.0 }\end{aligned}$




\section{Forecasted Confired Cases in West Bengal By Arima $(1,3,1)$ For the month of June, July, August}

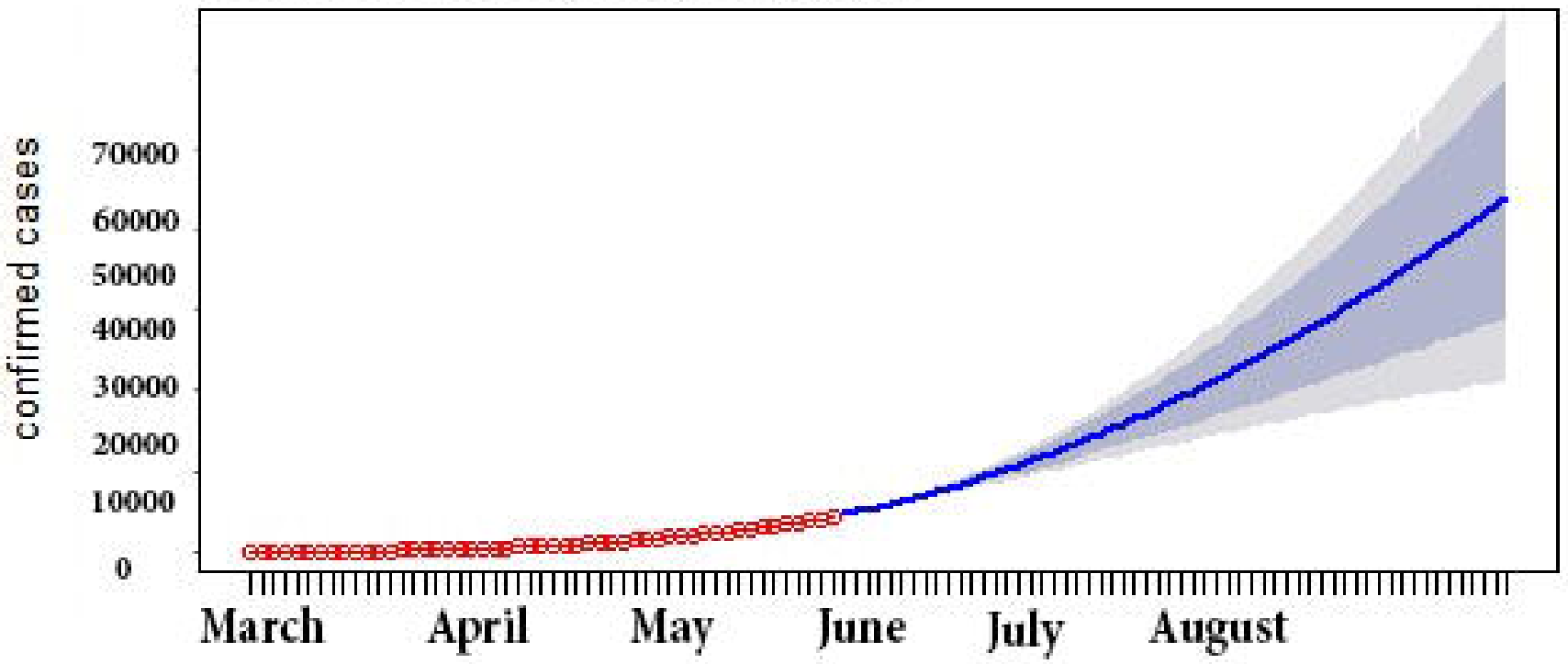

Date 
Forecasted COVID-19 Cases - $62279 \pm 5000$ a Cases by Trend

a Forecast

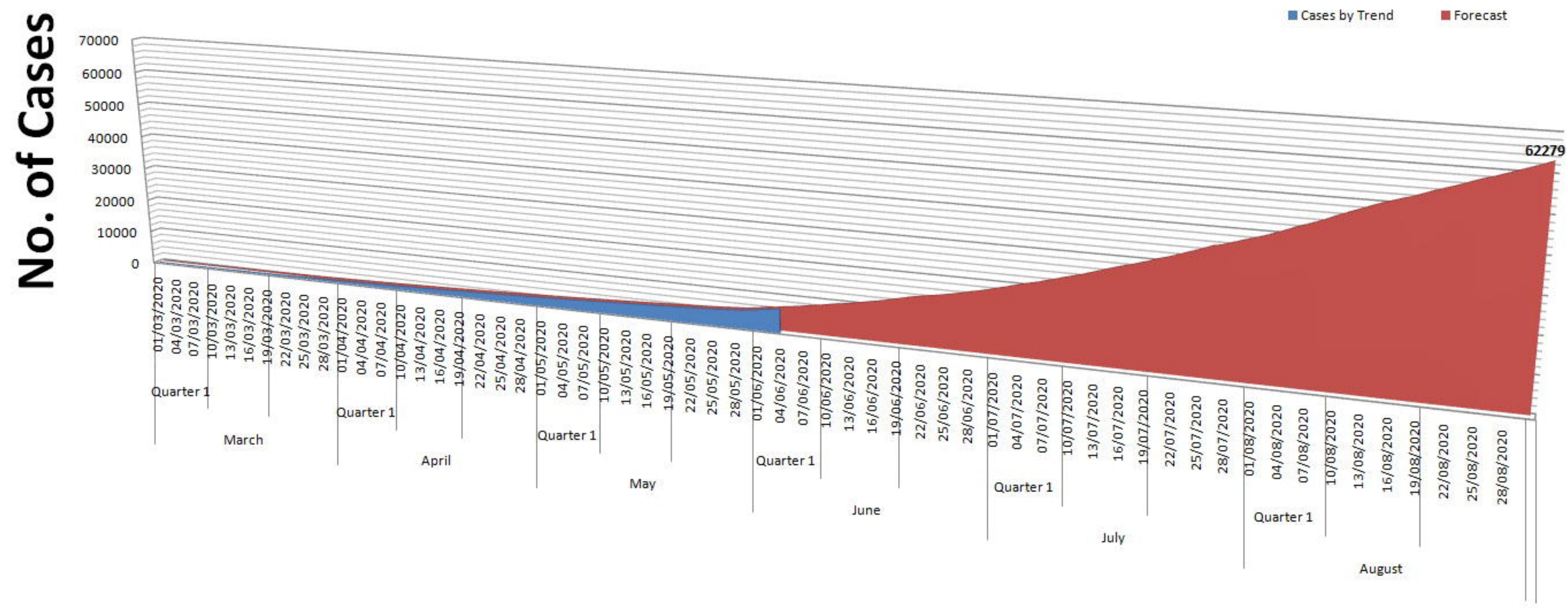

\section{Months}

